\title{
Implications for Emergency Response to the Severe Odor Incident Occurred in Source Water: Potential Odorants and Control Strategy
}

\author{
Qingyuan Guo ( $\nabla$ qyguon986@126.com ) \\ Yancheng Institute of Technology \\ Zhaoxia Li \\ Yancheng Institute of Technology \\ Tianming Chen \\ Yancheng Institute of Technology \\ Bairen Yang \\ Yancheng Institute of Technology \\ Cheng Ding \\ Yancheng Institute of Technology
}

\section{Research Article}

Keywords: medicinal odor, chemical odor, odorants identification, emergency management, powdered activated carbon (PAC)

Posted Date: June 1st, 2021

DOI: https://doi.org/10.21203/rs.3.rs-246665/v1

License: (-) (i) This work is licensed under a Creative Commons Attribution 4.0 International License. Read Full License

Version of Record: A version of this preprint was published at Environmental Science and Pollution Research on July 9th, 2021. See the published version at https://doi.org/10.1007/s11356-021-15218-1. 


\section{Abstract}

Sudden odor incidents occurring in the source water have been a severe problem for water suppliers. In order to apply emergency control measures effectively, it is necessary to identify the target compounds responsible for odor incidents rapidly. The present work identified the odorants and explored emergency disposal mechanisms for sudden and severe odors in the QT River's drinking water source (HZ city, China). Medicinal, chemical, septic, and musty odors with strong intensities were detected in the source water. The effect of conventional treatments of drinking water treatment plant (DWTP) on odors' removal was limited, which was evident by the presence of medicinal, chemical, and musty odors with moderate intensities in the effluent of DWTP. Total seventeen odorants were identified successfully in the source water of QT River and the effluent of DWTP. The measured OAVs and reconstituting the identified odorants explained $87 \%$, $87 \%, 89 \%$, and $94 \%$ of medicinal, chemical, septic, and musty odors, respectively, in the source water of the QT River and $90 \%, 87 \%$, and $88 \%$ of medicinal, chemical, and musty odors in the effluent. Styrene, phenol, 2-chlorophenol, 2-tert-butylphenol, and 2-methylphenol were associated with the medicinal odor, while propyl sulfide, diethyl disulfide, propyl disulfide, and indole were related to the septic odor. Geosmin and 2methylisoborneol (2-MIB) were responsible for the musty odor, and cyclohexanone, 1,4-dichlorobenzene, and nitrobenzene were involved with the chemical odor. Based on the characteristics of identified odorants, powdered activated carbon (PAC) was applied to control the odors in the QT River. The results indicated that the medicinal, chemical, septic, and musty odors could be removed entirely after adding $15 \mathrm{mg} / \mathrm{L} \mathrm{PAC}$, which effectively controlled emergency odor problems. Overall, the study would offer a scientific basis and operational reference for emergency odor management and control in DWTP with similar complicated odor incidents.

\section{Introduction}

As a sudden and emergency event in drinking water source, odor incident is a severe problem for water suppliers in many countries (Suffet et al. 2004; Yang et al. 2008; Guo et al. 2015). Some examples are Tai Lake with complex odor in 2007 (Wuxi, China) (Yang et al. 2008), Elk River with licorice odor in 2014 (Virginia, America) (Sain et al. 2015), and olive oil odor event in drinking water in 2013 (Barcelona, Spain) (Quintana et al. 2016). These odor incidents led to water supply cut off, aroused panic among consumers, and provoked a stir in society (Suffet et al. 2004; Watson 2004; Yang et al. 2008). Compared to longstanding odors with weak intensities caused by a microorganism, sudden odor incidents with strong intensities in source water are more linked to industrial chemical spills (Watson 2004; Wang et al. 2019b). Intakes of drinking water treatment plants (DWTP) are terminated of severe odors and contaminations in the source water. Accordingly, more measures should be taken to protect public health (Watson 2004; Yang et al. 2008). To effectively treat the severe odor incidents in DWTP, it is necessary to figure out the target compounds responsible for the odors because there are different emergency treatment technologies for corresponding classes of odor-causing compounds. Activated carbon adsorption preferably removes 2methylisoborneol (2-MIB) and geosmin with musty/earthy odor, while oxidation easily removes thioether compounds with septic/rancid odor (Guo et al. 2016a; Huang et al. 2020). 
Furthermore, the emerged odor incidents in the water matrix identified as more severe and complex issues in recent years (Yu et al. 2009; Sain et al. 2015; Li et al. 2019; Guo et al. 2020). The characterization of odors and corresponding odorants in complicated odor incidents originated from industrial chemical contamination, and spills have always been a challenge (Dietrich et al. 2015; Sain et al. 2015; Guo et al. 2016b). Once an odor incident breaks out, three-prong processes could be adopted by the water supply company to control the odors effectively. These include sensory analysis to describe odor issues, chemical analysis to determine the identities and concentrations of odorants, and treatment to minimize or remove odors (Dietrich et al., 2014).

Generally, the gas chromatography with mass spectrometry (GC/MS), especially with olfactory port (GC/O), identifies the odorants in the water matrix (Yu et al. 2009; Guo et al. 2019b). Recently, with rapid development in analytical technologies, the advanced chromatography and the detectors, including comprehensive two-dimensional gas chromatography (GC/GC) with more separating power, time of flight mass spectrometry with more sensitivity, and triple quadrupole tandem mass spectrometry with highresolution ratio, are used to identify and determine indiscernible odorants in complex odor events (Adahchour et al. 2008; Guo et al. 2016b; Wang et al. 2019a). Mainly, the combination of the above technologies is a valuable and practical way to identify complex odorants. GC/GC had been used to identify indiscernible odorants corresponding to olfactometry peaks evaluated by GC/O (Chin et al. 2011; Guo et al. 2019b). Odor activity values (OAVs) and reconstitution tests confirmed the identified compounds' odor contribution (Benkwitz et al. 2012; Guo et al. 2019a). The above approaches have successfully identified and confirmed the odor-causing compounds in the food industries, including coffee, wine, fruit, and the water matrix (Chin et al. 2011; Benkwitz et al. 2012; Guo et al. 2020).

There are several emergency disposal technologies for odor removal, including switching the odor water source with a new water source and adding powdered activated carbon (PAC), potassium permanganate chlorine, and chloramine (Ma et al. 2012; Omoike et al. 2019; Huang et al. 2020). According to the characteristics of odor incidents and equipment facilities at DWTP, appropriate emergency disposal technology and measures could be adopted for water suppliers for sudden odor incidents. Switching the odor water source with a new water source is limited to certain places or cities with an alternate water source (Hu et al. 2018). The addition of potassium permanganate is sufficient to control the growth of odor-producing algae and remove colors and odors to some extent. However, the overdose of potassium permanganate results in red-violet color (Ma et al. 2012; Omoike et al. 2019). Chlorination has some removal effect on the odors caused by reductive compounds such as thioethers, thiols, etc (Ma et al. 2016). Notably, the musty odor caused by 2-MIB and geosmin could not be removed effectively by oxidation of potassium permanganate, chlorine, and chloramine (Antonopoulou et al. 2014; Ma et al. 2016). Compared with the mentioned emergency technologies and measures, PAC has advantages such as high removing efficiency for different category odorants and low investment cost (Huang et al. 2020). Thus, PAC is a practical approach to remove emergency odors for water suppliers and treat some source water seasonal odor problems (Matsui et al. 2010; He et al. 2016; Huang et al. 2019; Huang et al. 2020). 
Serious odor problems suddenly emerged in drinking water supplies from QT River in HZ city, China, which lasted one month approximately. Consequently, countless consumer complaints were received by environmental protection agencies. The present study identifies the odor-causing compounds and their emergency disposal in DWTP using conventional processes, including coagulation, sedimentation, sand filtration, and chlorination, to clarify and control the unfamiliar odor problems. The study has attempted to identify target odor-causing compounds and take emergency measures. The present work would offer a scientific basis and operational reference for DWTP's emergency odor management for sudden odor incidents.

\section{Materials And Methods}

\section{Chemicals and reagents}

The authentic standards of odorants of the highest purity level, as shown in Table S1, were purchased from Sigma-Aldrich (USA). Solvents and reagents, including dichloromethane, methanol, and alkanes (C7C30), of HPLC grade, were purchased from Supelco Co. (USA). Ultrapure deionized water was obtained through a Milli-Q purification system $\left(18 \mathrm{M} \Omega{ }^{*} \mathrm{~cm}\right)$.

\section{General situation of odor incident}

Since December $10^{\text {th }}, 2013$, serious odor problems suddenly emerged in drinking water supplies from QT River in HZ city, China, and lasted approximately one month (Table S2). On the first day of the odor outbreak, the environmental protection agency received 112 complaints from consumers. The identification of odor-causing compounds and urgently disposal of odors by PAC were conducted for clarifying and controlling this abnormal odor problems immediately. Until January $10^{\text {th }}, 2014$, the upstream pollution source was identified and closed. Subsequently, the PAC addition was stopped and ended the odor incident.

\section{Sampling and preparation}

The study investigated the source water and effluent of QT DWTP when the odor incident occurred. QT DWTP adopted conventional coagulation, sedimentation, sand filtration, and chlorination and used QT River as the water source. Amber glass bottles (one liter) were filled with the water samples from source water and effluent of DWTP. Water samples were immediately transported to the laboratory using an insulated box with ice bags to maintain the temperature below $4{ }^{\circ} \mathrm{C}$. Flavor profile analysis (FPA) evaluated the odor characteristics. Also, the pre-concentration of liquid-liquid extraction (LLE) and the instrumental analyses, including GC/MS/MS, GC/O, and GC/GC, was accomplished (Guo et al. 2016b; Wang et al. 2019a). The previous study considered the effect of collecting and transporting water samples on odorants' variation based on specific measures, including amber glass bottles, insulated boxes, ice bags, etc., to prevent the change in water quality. However, the sensory evaluation and odorant analysis between in-situ experiments and laboratory operations indicated no significant differences (Guo. 2016c). In the 
present study, each water sample was analyzed in parallel, and the concentrations of identified odorants were averaged for the duplicate analyses.

\section{Sensory analysis}

The FPA evaluated the odor characteristics of water samples (APHA, 2005). Seven-point scales from 1 to 12 described the odor intensity explained as 1 : threshold value, 2: very weak odor intensity, 4 : weak odor intensity, 6\&8: moderate odor intensity, 10\&12: strong odor intensity. The panelists were carefully screened and trained to guarantee the accuracy of sensory analysis. 3-6 non-smokers with normal olfactory function are usually recommended in the method. In this study, 8-10 panelists with ages between 24 and 45 years conducted the sensory analysis of odors. The training and procedures could be found in Standard Methods for Water and Wastewater (APHA, 2005). The 3-alternative forced-choice (3-AFC) method determined the odor threshold concentration (OTC) of the related odor-causing compound (ASTM, 1997). The odor evaluating panelists also assessed the water sample extracts passed through GC-O/MS.

\section{Odorants' analyses by GC-0, GC/GC, and GC/MS/MS}

The GC/O and GC/GC analysis identified the odorants in source water and effluent of DWTP with QT River as a water source (Guo et al. 2016b). The GC/MS/MS performed the odorant's quantitative analysis (Wang et al. 2019a). Odor activity value (OAV) and reconstitution test evaluated and confirmed the detected odorants' contributions to the whole odor profile (Benkwitz et al. 2012). The odor contribution ratio of reconstituted sample to primary sample was calculated by dividing the specific odor intensity of reconstituted sample by the corresponding odor intensity of the primary sample.

\section{Emergency control of odor problems occurred in QT River for DWTP}

For emergency management and control of the odor problems in the QT River, laboratory batch tests of activated carbon adsorption of odors were conducted. $0 \mathrm{mg} / \mathrm{L}, 5 \mathrm{mg} / \mathrm{L}, 10 \mathrm{mg} / \mathrm{L}, 15 \mathrm{mg} / \mathrm{L}$, and $20 \mathrm{mg} / \mathrm{L}$ of PAC (F325) were added in $500 \mathrm{~mL}$ source water samples from QT River in conical flasks and oscillated for $30 \mathrm{~min}$ at $150 \mathrm{rpm} / \mathrm{min}$ frequency. The FPA performed the sensory analyses of the source waters in the conical flasks to evaluate the effect of PAC on odor removal. Finally, the optimized PAC dose of $15 \mathrm{mg} / \mathrm{L}$ was supplied to the DWTP and added to the coagulation process's water intake. The FPA evaluated the sample collected from the DWTP effluent to realize PAC's emergency odor control effect.

\section{Results And Discussion}

\section{Odor characteristics of source water and effluent of DWTP}

Fig.1 shows the odor categories and intensities of source water and effluent from QT DWTP. Four odor categories, including medicinal, chemical, musty, and septic odors, with intensities of 11 12, 11.4 12, 10.7 11.7, and 11.3 11.9, respectively, were detected in source water, suggesting severe and complicated odor characteristics in the QT River. After conventional coagulation, sedimentation, filtration, and disinfection, the odor characteristics were changed to medicinal, chemical, and musty odors with 
intensities of 6.4 9.2, 6.7 9.7, 6.8 9.2, respectively. Odor intensities of source water reached a strong scale (the maximum odor intensity), while odor intensities of effluent reached a moderate scale, indicating the critical odor situations in the QT River. Generally, musty odor is associated with the metabolism of microbes such as algae and bacteria activities (Li et al. 2012a; Zhang et al. 2013; Li et al. 2018), while medicinal, chemical, and septic odors are more related to exogenous pollutions (Suffet et al. 2004; Watson 2004; Agus et al. 2012). The odor characteristics are further elaborated with odor-causing compounds in the next section.

\section{Odorants identified in source water of QT River and effluent of DWTP}

Sensory evaluation of source water and effluent from DWTP located at QT River detected medicinal, chemical, musty, and septic odors with moderate or strong intensities (Fig. 1). It is noteworthy that the GC/O detected more olfactory odor peaks, as shown in Fig. 2, 3, and Table 1. Fourteen olfactory odor peaks, including four medicinal peaks, three chemical peaks, two musty peaks, four septic peaks, and one fishy peak, were detected in the QT River source water. Post conventional processes, there were still nine olfactory odor peaks, including four medicinal peaks, two chemical peaks, two musty peaks, and one fishy peak, detected in the effluent of DWTP. The GC/O detected olfactory odor peaks were almost consistent with the sensory evaluation outcomes. Among identified olfactory odor peaks, peak number (No.) 6, 7, 8, 11,13 , and 14 were all detected both in the source water and effluent, while, No. 1, 2, 3, 4, 5, 9, 10, 12 were only identified in the source water, and No. 15, 16, 17 in the effluent. Total seventeen olfactory odor peaks, including five medicinal peaks, four chemical peaks, two musty peaks, four septic peaks, and two fishy peaks, were detected in the QT River source water and DWTP effluent. The GC/GC analysis (Fig. S1) successfully screened and identified seventeen odor-causing compounds (Table 1), corresponding to the $\mathrm{GC} / \mathrm{O}$ detected seventeen olfactory odor peaks.

Table 1 shows the identified relevant odorants for medicinal peaks No.1, 6, 7, 13, and 17 as styrene, phenol, 2-chlorophenol, 2-tert-butylphenol, and 2-methylphenol, respectively. Usually, phenolic odorants with medicinal odors associated with agriculture and industry are frequently detected in drinking and wastewaters (Davi et al. 1999; Agus et al. 2012). Especially, 2-tert-butylphenol, which is a typical industrial product of antioxidant, medical intermediate, pesticide intermediate, perfume raw material, etc., has been detected as a typical odor-causing compound in the cross-linked polyethylene pipes used for drinking water supply (Liu et al. 2017; Kalweit et al. 2019). The studies reported that the phenolic compounds detected in the source water are related to industrial sewage discharge (Chen et al., 2018). Fortunately, these compounds are rarely identified in the source and finished waters without industrial contamination.

The chemical odors for olfactory peaks No. 3, 8, 9, 15 were identified as cyclohexanone, 1,4dichlorobenzene, nitrobenzene, and cis-3-hexenol. Benzene compounds are usually deemed essential chemical products and mainly obtained from coking, gasoline, and petroleum industries (Botalova et al. 2009). In contrast, cyclohexanone and cis-3-hexenol mainly involved with industrial solvents, additives for perfumes, and wastewater discharge (Mayuoni-kirshinbaum et al. 2012; Sheng et al. 2016). The odor descriptor for cis-3-hexenol reported green, grassy, melon rind-like with a pungent freshness (Watson. 2004). However, the olfactometry peak descriptor reported grassy, chemical, plastic by the FPA panel. The 
results might be related to odor characteristics' variation at different impact factors such as exposed subjects, naïve subjects, and concentration of odorants (Gallagher et al. 2015; Guo et al. 2019a).

The septic odor peaks of No. 2, 5, 10, and 12 were identified as propyl sulfide, diethyl disulfide, propyl disulfide, and indole. In the preceding odor studies across China, thioethers were discovered as significant septic/marshy odor-causing compounds (Guo et al. 2015; Wang et al. 2019b). These septic odor compounds were mainly associated with domestic pollution, industrial sewages, agricultural operations, etc (Schiffman et al. 2001; Liu et al. 2012; Lu et al. 2013).

The detection of various artificial compounds, such as phenols, benzenes, sulfides, etc., indicated that the water matrix of QT River was suffered from exogenous pollutions (Hu et al. 2020; Liu et al. 2021). The QT river is situated near the most agricultural, urban, and industrial areas in China, resulting in easy water contamination by exogenous pollutions. Supplementary protection procedures need to be adopted to alleviate the future risk of odor occurrence in the QT River. Significantly, the polluting factories should strictly adhere to the effluent standards. Also, cleaner production and end treatment should be strengthened in the production processes of polluting factories and enterprises. Otherwise, the risk of source water contamination from the QT River could emerge.

The olfactory peaks No. 11 and 14 with musty odors were recognized as 2-MIB and geosmin, respectively, the principal musty/earthy odorants in the worldwide water matrix (Lin et al. 2002; Watson 2004; Li et al. 2019), mainly produced by cyanobacteria and actinomycetes (Suffet et al. 1999; Li et al. 2012b; Sun et al. 2013). The olfactory peaks No. 4 and 16 with fishy odors were identified as heptanal and 2,4-heptadienal, respectively, which were reported to be found in fishy odor events and mainly associated with algal metabolites (Watson 2004). The presence of 2-MIB, geosmin, heptanal, and 2,4-heptadienal indicated that the microbial metabolism existed in the QT River. The detection of the above odorants, involved with exogenous pollution and microbial metabolism, suggested a high risk of odor incidents in the QT River and the subsequent need for further attention and protection in the future.

\section{Evaluation and confirmation of identified odorants}

Table 1 listed the identified odorants in source water and effluent of DWTP located at QT River in December 2013. A total of seventeen detected compounds were quantified (Fig. S2), and OAVs were measured to evaluate the identified odorants' contribution to source water and effluent odors. Fig. 4 demonstrates the identified compounds sorted based on their odor features and material structures as medicinal odorants (styrene, phenol, 2-chlorophenol, 2-tert-butylphenol, and 2-methylphenol), chemical odorants (cyclohexanone, 1,4-dichlorobenzene, nitrobenzene, and cis-3-hexenol), stink odorants (propyl sulfide, diethyl disulfide, propyl disulfide, and indole), musty odorants (2-MIB and geosmin) and fishy odorants (heptanal and 2,4-heptadienal).

Among the identified odorants in the source water of the QT River, the concentrations of styrene, phenol, 2chlorophenol, and 2-tert-butylphenol with medicinal odors were 255 345, 252 342, 186 252, and $264 \sim 358 \mathrm{ng} / \mathrm{L}$, respectively. The conventional coagulation, sedimentation, filtration, and disinfection, 
reduced the concentrations of the residual phenol, 2-chlorophenol, and 2-tert-butylphenol to 170 230, 160 216, and 179 243 ng/L, respectively. Usually, compounds with OAVs $>1$ are considered crucial to the corresponding odor characteristics (Benkwitz et al. 2012). Based on measured OAV and rank of identified odorants in the QT River, 2-chlorophenol and 2-tert-butylphenol were considered major medicinal odor compounds. Geosmin and 2-MIB with OAVs of 8 10 and 7 9 in the source water and 6 8 and 4 6 in the effluent were significant compounds responsible for musty odor. OAVs of propyl sulfide, diethyl disulfide, propyl disulfide, and indole in the source water were 5 6, 1 2, 3 4, and 0.8 1.0, respectively, as major septic odorants in the QT River. Interestingly, the concentrations of chemical odorants were lower than their corresponding OTCs. However, the chemical odor intensities in the source water and effluent were strong and moderate, respectively. The observed result could be associated with the synergistic effect among odorants (Watson 2004; Guo et al. 2019a). Thus, it is necessary to verify the identified odorants' mutual odor effect by reconstitution test.

After the DWTP's conventional process, the effluent exhibited 2-methylphenol with a medicinal odor, cis-3hexenol with a grassy/chemical odor, 2,4-heptadienal with a fishy odor. The observed concentrations of 2methylphenol, cis-3-hexenol and 2,4-heptadienal in the effluent were 150 204 ng/L, 178 240 ng/L, and $101 \sim 137 \mathrm{ng} / \mathrm{L}$, respectively. Compared with high OTCs of $14700 \mathrm{ng} / \mathrm{L}$ (2-methylphenol), $1200 \mathrm{ng} / \mathrm{L}$ (cis-3hexenol), and $5000 \mathrm{ng} / \mathrm{L}$ (2,4-heptadienal), OAVs of these three emerged odorants were less than 1 , confirming these compounds could not be major odor contributors.

Fig. 5 and Table S3 demonstrate the comparison of odor characteristics of primary samples and reconstituted water samples. Odor intensities of medicinal, chemical, septic, and musty odors in the reconstituted water sample could explain $87 \%, 87 \%, 89 \%$, and $94 \%$ of corresponding odors in the source water from the QT River. Similarly, reconstituting identified odorants could explain $90 \%, 87 \%$, and $88 \%$ of medicinal, chemical, and musty odors, respectively, in the effluent. Almost all odorants in the odor incident in the QT River were screened and identified in this study. The musty odor was mainly caused by geosmin and 2-MIB, medicinal odor was mainly caused by 2-chlorophenol and 2-tert-butylphenol, septic odor was caused by propyl sulfide, propyl disulfide, diethyl disulfide, and indole. The result was consistent with the OAVs' evaluation to identify odorants (Fig. 4). $87 \%$ of chemical odors' explanation in the reconstituted samples suggested that the major compounds causing chemical odor were identified and verified. Considering OAVs $<1$ for compounds causing chemical odors, the synergistic odor effect of other odorants on chemical odor is possible (Watson 2004). Even though all identified odorants were added in the reconstituted water samples, odor intensities of primary samples could not be explained $100 \%$, indicating that the odor incident of QT River was complicated and might be affected by other materials. As observed, odor-causing compounds under the limit of detection concentrations might be undetected, and other coexisting organic matters without odors could influence the whole odor profiles (Li et al. 2020).

\section{Effect of PAC on removing odors in source water of QT River}

Fig. 1 illustrates the odor characteristics of effluent from DWTP after the coagulation, sedimentation, filtration, and disinfection process. The results showed intensities for medicinal odor as 6.4 9.2, chemical odor as 6.7 9.7, and musty odor as 6.8 9.2. Fig. 4 shows the OAVs of geosmin with a musty odor, 2-MIB 
with a musty odor, 2-chlorophenol with medicinal odor, and 2-tert-butylphenol with medicinal odor in the effluent were still greater than 1 . Thus, these odorants contribute significantly to the effluent's odor profile. These results indicated that the effect of conventional processes on odors' removal is limited. For emergency control of odors occurring in the source water of QT River, laboratory batch tests of activated carbon adsorption of odors of the source water from the QT River were performed. As shown in Fig. 6, an increase in PAC dosage improved the effect of PAC on odor removal. The addition of $15 \mathrm{mg} / \mathrm{L}$ of PAC followed by 30 min oscillation exhibited no odors detected in the source water sample from QT River. Immediately, the emergency control measure of $15 \mathrm{mg} / \mathrm{L}$ PAC was fed to the DWTP, which resulted in the complete removal of effluent odors (Fig. S3). PAC has proved to be an effective way to control emergency odor problems. The factors influencing the PAC adsorption, including $\mathrm{pH}$, natural organic matter (NOM), operating conditions of PAC addition, etc., should be recognized in practical situations ( $\mathrm{Li}$ et al. 2015). However, considering the pressing circumstances of emergency treatment and management of odor incidents in the source water, the specific conditions to use PAC and the associated problems need to be investigated in the future.

\section{Conclusion}

The paper focused on the comprehensive study of the emergency response, including potential odorants and control strategy, to an odor incident in the QT River located at HZ City, China. The medicinal, chemical, septic, and musty odors with strong intensities were detected in the source water of QT River. The medicinal, chemical, and musty odors with moderate intensities were still detected in the effluent of DWTP after the conventional processes of coagulation, sedimentation, sand filtration, and chlorination. Combination of GC/O and GC/GC successfully identified seventeen odor-causing compounds in source water and effluent of DWTP with QT River as the water source. The measured OAVs and reconstituting identified odorants could explain $87 \%, 87 \%, 89 \%$, and $94 \%$ of medicinal, chemical, septic, and musty odors, respectively, in the source water from the QT River and $90 \%, 87 \%$, and $88 \%$ of medicinal, chemical, and musty odors, respectively, in the effluent. Styrene, phenol, 2-chlorophenol, 2-tert-butylphenol, and 2methylphenol were associated with the medicinal odor, while propyl sulfide, diethyl disulfide, propyl disulfide, and indole were related to the septic odor. Geosmin and 2-MIB were responsible for the musty odor, and cyclohexanone, 1,4-dichlorobenzene, and nitrobenzene might be involved with the chemical odor. The effect of conventional processes of DWTP on odors' removal was limited, which was evident by the presence of medicinal, chemical, and musty odors of moderate intensities in the effluent of DWTP. For emergency management and control of odor incidents in the QT River, the addition of PAC with gradient concentrations was optimized through batch tests. Medicinal, chemical, septic, and musty odors could be removed entirely by $15 \mathrm{mg} / \mathrm{L}$ of PAC, indicating an effective way for odors' removal in DWTP. The present study accomplished odor analyses and control of emergencies to offer a scientific basis and operational reference for DWTP's emergency odor management in complicated odor incidents.

\section{Declarations}


Acknowledgements This study was supported by Funds for the National Natural Science Foundation of China (No. 21707117, 51878587), China Postdoctoral Science Foundation Grant (2018M631602), Jiangsu Natural Science Foundation of China (No. BK20160438).

Authors' contributions Qingyuan Guo: Conceptualization, Software, Writing - Original Draft. Zhaoxia Li: Validation, Visualization, Formal analysis. Tianming Chen: Data curation, Methodology. Bairen Yang: Investigation, Project administration. Cheng Ding: Conceptualization, Supervision. All authors read and approved the final manuscript.

Data availability All data generated or analyzed during this study are included in this published article (and its supplementary information files).

\section{Compliance with ethical standards}

Conflict of interest The authors declare that they have no conflicts of interest.

Ethical approval Not applicable.

Consent to participate Not applicable.

Consent to publish Yes.

\section{References}

1. Adahchour M, Beens J, Brinkman UAT (2008) Recent developments in the application of comprehensive two-dimensional gas chromatography. J Chromatogr A 1186(1-2): 67-108.

2. Agus $E$, Zhang LF, Sedlak DL (2012) A framework for identifying characteristic odor compounds in municipal wastewater effluent. Water Res 46(18): 5970-5980.

3. Antonopoulou M, Evgenidou E, Lambropoulou D, Konstantinou I (2014) A review on advanced oxidation processes for the removal of taste and odor compounds from aqueous media. Water Res 53: 215-234.

4. APHA (2005) Standard methods for the examination of water and wastewater. APHA American Public Health Association.

5. ASTM (1997) Standard Practice Designation E 679-91. American Society for Testing and Materials 3438.

6. Benkwitz F, Nicolau L, Lund C, Beresford M, Wohlers M, Kilmartin PA (2012) Evaluation of Key Odorants in Sauvignon Blanc Wines Using Three Different Methodologies. J Agric Food Chem 60(25): 6293-6302.

7. Botalova O, Schwarzbauer J, Frauenrath T, Dsikowitzky L (2009) Identification and chemical characterization of specific organic constituents of petrochemical effluents. Water Res 43(15): 37973812 . 
8. Chen F, Tang F, Xu J, Wang Y, Ruan D, Zhang W, Zhou S (2018) Pollution characteristics and health risk assessment of volatile organic compounds (VOCs) and semi-volatile organic compounds (SVOCs) in QT river's HZ section during a water odor pollution event. Environ Sci (Chinese) 39(2): 648-654.

9. Chin S-T, Eyres GT, Marriott PJ (2011) Identification of potent odourants in wine and brewed coffee using gas chromatography-olfactometry and comprehensive two-dimensional gas chromatography. $J$ Chromatogr A 1218(42): 7487-7498.

10. Davi ML, Gnudi F (1999) Phenolic compounds in surface water. Water Res 33(14): 3213-3219.

11. Dietrich AM, Phetxumphou K, Gallagher DL (2014) Systematic tracking, visualizing, and interpreting of consumer feedback for drinking water quality. Water Res 66: 63-74.

12. Dietrich AM, Thomas A, Zhao Y, Smiley E, Shanaiah N, Ahart M, Charbonnet KA, DeYonker NJ, Alexander WA, Gallagher DL (2015) Partitioning, Aqueous Solubility, and Dipole Moment Data for cisand trans-(4-Methylcyclohexyl)methanol, Principal Contaminants of the West Virginia Chemical Spill. Environ Sci Technol Letters 2(4): 123-127.

13. Gallagher DL, Phetxumphou K, Smiley E, Dietrich AM (2015) Tale of Two Isomers: Complexities of Human Odor Perception for cis-and trans-4-Methylcyclohexane Methanol from the Chemical Spill in West Virginia. Environ Sci Technol 49(3): 1319-1327.

14. Guo Q, Li X, Yu J, Zhang H, Zhang Y, Yang M, Lu N, Zhang D (2015) Comprehensive two-dimensional gas chromatography with time-of-flight mass spectrometry for the screening of potent swampy/septic odor-causing compounds in two drinking water sources in China. Anal Methods 7(6): 2458-2468.

15. Guo Q, Yu J, Su M, Wang C, Yang M, Cao N, Zhao Y, Xia P (2019a) Synergistic effect of musty odorants on septic odor: Verification in Huangpu River source water. Sci Total Environ 653: 1186-1191.

16. Guo Q, Yang K, Yu J, Wang C, Wen X, Zhang L, Yang M, Xia P, Zhang D (2016a) Simultaneous removal of multiple odorants from source water suffering from septic and musty odors: Verification in a fullscale water treatment plant with ozonation. Water Res 100: 1-6.

17. Guo Q, Yu J, Yang K, Wen X, Zhang H, Yu Z, Li H, Zhang D, Yang M (2016b) Identification of complex septic odorants in Huangpu River source water by combining the data from gas chromatographyolfactometry and comprehensive two-dimensional gas chromatography using retention indices. Sci Total Environ 556: 36-44.

18. Guo Q (2016c) Identification and control of septic odor causing compounds in a river-type source water of south China. Doctoral Thesis.

19. Guo Q, Yu J, Zhao Y, Liu T, Su M, Jia Z, Zhao Y, Mu Z, Yang M (2019b) Identification of fishy odor causing compounds produced by Ochromonas sp. and Cryptomonas ovate with gas chromatographyolfactometry and comprehensive two-dimensional gas chromatography. Sci Total Environ 671: 149156.

20. Guo Q, Yu J, Li X, Chen T, Wang C, Li Z, Ma W, Ding C, Yang M (2020) A systematic study on the odorants characterization and evaluation in a plain reservoir with wetlands ecosystem. $\mathrm{J}$ Hazard Mater 393. 
21. He Q, Zhong L, Wang H, Zou Z, Chen D, Yang K (2016) Odor removal by powdered activated carbon (PAC) in low turbidity drinking water. Water Sci Technol Water Sci Technol 16(4): 1017-1023.

22. Hu J, Dong H, Xu Q, Ling W, Qu J, Qiang Z (2018) Impacts of water quality on the corrosion of cast iron pipes for water distribution and proposed source water switch strategy. Water Res 129: 428-435.

23. Hu RY, Liu GJ, Zhang H, Xue HQ, Wang X, Lam PKS (2020) Odor pollution due to industrial emission of volatile organic compounds: A case study in Hefei, China. J Clean Prod 246: 1-11.

24. Huang X, Lu Q, Hao H, Wei Q, Shi B, Yu J, Wang C, Wang Y (2019) Evaluation of the treatability of various odor compounds by powdered activated carbon. Water Res 156: 414-424.

25. Huang X, Shi B, Hao H, Su Y, Wu B, Jia Z, Wang C, Wang Q, Yang M, Yu J (2020) Identifying the function of activated carbon surface chemical properties in the removability of two common odor compounds. Water Res 178.

26. Kalweit C, Stottmeister E, Rapp T (2019) Contaminants migrating from crossed-linked polyethylene pipes and their effect on drinking water odour. Water Res 161: 341-353.

27. Li X, Wang J, Zhang X, Chen C (2015) Powdered activated carbon adsorption of two fishy odorants in water: Trans, trans-2,4-heptadienal and trans, trans-2,4-decadienal. J Environ Sci 32: 15-25.

28. Li L, Yang S, Yu S, Zhang Y (2019) Variation and removal of 2-MIB in full-scale treatment plants with source water from Lake Tai, China. Water Res 162: 180-189.

29. Li L, Li J, Zhu C, Yu S (2020) Study of the binding regularity and corresponding mechanism of drinking water odorous compound 2-MIB with coexisting dissolved organic matter. Chem Eng J 395: 125015.

30. Li L, Gao NY, Deng Y, Yao J, Zhang K (2012a) Characterization of intracellular \&amp; extracellular algae organic matters (AOM) of Microcystic aeruginosa and formation of AOM-associated disinfection byproducts and odor \&amp; taste compounds. Water Res 46(4): 1233-1240.

31. Li L, Zhu C, Xie C, Shao C, Yu S, Zhao L, Gao N (2018) Kinetics and mechanism of Pseudoanabaena cell inactivation, 2-MIB release and degradation under exposure of ozone, chlorine and permanganate. Water Res 147: 422-428.

32. Li Z, Hobson P, An W, Burch MD, House J, Yang M (2012b) Earthy odor compounds production and loss in three cyanobacterial cultures. Water Res 46(16): 5165-5173.

33. Lin TF, Wong JY, Kao HP (2002) Correlation of musty odor and 2-MIB in two drinking water treatment plants in South Taiwan. Sci Total Environ 289(1-3): 225-235.

34. Liu J, Lu C, Huang L, Sun J, Yue P, Liu X, Kang X (2021) Performance and economic analyses of a combined bioreactor for treating odors, volatile organic compounds, and aerosols from a landfill site. J Clean Prod 278.

35. Liu H, Luo G-Q, Hu H-Y, Zhang Q, Yang J-K, Yao H (2012) Emission characteristics of nitrogen- and sulfur-containing odorous compounds during different sewage sludge chemical conditioning processes. J Hazard Mater 235: 298-306.

36. Liu ZH, Yin H, Dang Z (2017) Do estrogenic compounds in drinking water migrating from plastic pipe distribution system pose adverse effects to human? An analysis of scientific literature. Environ Sci Pollut R 24(2): 2126-2134. 
37. Lu X, Fan C, He W, Deng J, Yin H (2013) Sulfur-containing amino acid methionine as the precursor of volatile organic sulfur compounds in algea-induced black bloom. J Environ Sci 25(1): 33-43.

38. Ma C, Shi WX, Wang L, Zhao X, Zhao B, Guo XF, Zhang ZH, Zhang HW (2016) Effect of disinfection method on odor and disinfection byproduct control in drinking water treatment. Desalination Water Trea 57(17): 7753-7762.

39. Ma X, Hu S, Wang H, Li J, Huang J, Zhang Y, Lu W, Li Q (2012) Kinetics of oxidation of dimethyl trisulfide by potassium permanganate in drinking water. Front Environ Sci Eng 6(2): 171-176.

40. Matsui Y, Nakano Y, Hiroshi H, Ando N, Matsushita T, Ohno K (2010) Geosmin and 2-methylisoborneol adsorption on super-powdered activated carbon in the presence of natural organic matter. Water Sci Technol 62(11): 2664-2668.

41. Mayuoni-kirshinbaum L, Tietel Z, Porat R, Ulrich D (2012) Identification of aroma-active compounds in 'wonderful' pomegranate fruit using solvent-assisted flavour evaporation and headspace solid-phase micro-extraction methods. Eur Food Res Technol 235(2): 277-283.

42. Omoike Al, Harmon D (2019) Slow-releasing permanganate ions from permanganate core-manganese oxide shell particles for the oxidative degradation of an algae odorant in water. Chemosphere 223: 391-398.

43. Quintana J, Vegué L, Martín-Alonso J, Paraira M, Boleda MR, Ventura F (2016) Odor Events in Surface and Treated Water: The Case of 1,3-Dioxane Related Compounds. Environ Sci Technol 50(1): 62-69.

44. Sain AE, Dietrich AM, Smiley E, Gallagher DL (2015) Assessing human exposure and odor detection during showering with crude 4-(methylcyclohexyl)methanol (MCHM) contaminated drinking water. Sci Total Environ 538: 298-305.

45. Schiffman SS, Bennett JL, Raymer JH (2001) Quantification of odors and odorants from swine operations in North Carolina. Agr Forest Meteorol 108(3): 213-240.

46. Sheng X, Wang Q, Chen L, Shen Z, Pei Y (2016) Determination and Correlation for the Solubility of Glutaric Acid in Cyclohexane plus Cyclohexanol plus Cyclohexanone Solvent Mixtures. J Chem Eng Data 61(11): 3761-3769.

47. Suffet IH, Khiari D, Bruchet A (1999) The drinking water taste and odor wheel for the millennium: Beyond geosmin and 2-methylisoborneol. Water Sci Technol 40(6): 1-13.

48. Suffet IH, Schweitze L, Khiari D (2004) Olfactory and chemical analysis of taste and odor episodes in drinking water supplies. Rev Environ Sci Biotechnol 3(1): 3-13.

49. Sun D, Yu J, An W, Yang M, Chen G, Zhang S (2013) Identification of causative compounds and microorganisms for musty odor occurrence in the Huangpu River, China. J Environ Sci 25(3): 460-465.

50. Wang C, Yu J, Guo Q, Zhao Y, Cao N, Yu Z, Yang M (2019a) Simultaneous quantification of fifty-one odor-causing compounds in drinking water using gas chromatography-triple quadrupole tandem mass spectrometry. J Environ Sci 79: 100-110.

51. Wang C, Yu J, Guo Q, Sun D, Su M, An W, Zhang Y, Yang M (2019b) Occurrence of swampy/septic odor and possible odorants in source and finished drinking water of major cities across China. Environ Pollut 249: 305-310. 
52. Watson SB (2004) Aquatic taste and odor: a primary signal of drinking - water integrity. J Toxicol Env Heal A 67(20-22): 1779-1795.

53. Yang M, Yu J, Li Z, Guo Z, Burch M, Lin T-F (2008) Taihu Lake Not to Blame for Wuxi's Woes. Science 319(5860): 158-158.

54. Young WF, Horth H, Crane R, Ogden T, Arnott M (1996) Taste and odour threshold concentrations of potential potable water contaminants. Water Res 30(2): 331-340.

55. Yu JW, Zhao YM, Yang M, Lin T-F, Guo ZH, Gu JN, Li S, Han W (2009) Occurrence of odour-causing compounds in different source waters of China. J. Water Supply Res Technol 58(8): 587-594.

56. Zhang K, Lin TF, Zhang T, Li C, Gao N (2013) Characterization of typical taste and odor compounds formed by Microcystis aeruginosa. J Environ Sci 25(8): 1539-1548.

\section{Tables}

Table 1 Summary of characteristic olfactometry peaks and identified odorants in source water and effluent of DWTP located at QT River 


\begin{tabular}{|c|c|c|c|c|c|c|c|}
\hline $\begin{array}{l}\text { Peak } \\
\text { No. }\end{array}$ & $\begin{array}{l}\text { All } \\
\text { olfactometry } \\
\text { peak } \\
\text { descriptors } \\
\text { by FPA } \\
\text { panel }\end{array}$ & $\begin{array}{l}\text { Consensus } \\
\text { olfactometry } \\
\text { peak } \\
\text { descriptor }\end{array}$ & Compounds & 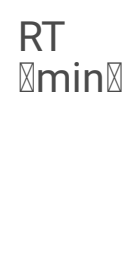 & $\mathrm{RI}$ & $\begin{array}{l}\text { Odor } \\
\text { description }\end{array}$ & Reference \\
\hline 1 & $\begin{array}{l}\text { Medicinal, } \\
\text { plastic }\end{array}$ & Medicinal & Styrene & 6.17 & 885 & $\begin{array}{l}\text { Medicinal, } \\
\text { paint, } \\
\text { Sweet }\end{array}$ & $\begin{array}{l}\text { (Young et } \\
\text { al. 1996; } \\
\text { Watson. } \\
\text { 2004) }\end{array}$ \\
\hline 2 & $\begin{array}{l}\text { Septic, } \\
\text { stinky }\end{array}$ & Septic & Propyl sulfide & 6.65 & 898 & $\begin{array}{l}\text { Septic, } \\
\text { marshy, } \\
\text { rotten egg }\end{array}$ & $\begin{array}{l}\text { (Suffet et } \\
\text { al. 2004; } \\
\text { Watson. } \\
\text { 2004) }\end{array}$ \\
\hline 3 & $\begin{array}{l}\text { Chemical, } \\
\text { solvent }\end{array}$ & Chemical & Cyclohexanone & 6.84 & 903 & $\begin{array}{l}\text { Chemical, } \\
\text { solvent }\end{array}$ & $\begin{array}{l}\text { (Suffet et } \\
\text { al. 2004; } \\
\text { Watson. } \\
\text { 2004) }\end{array}$ \\
\hline 4 & Fishy, oily & Fishy & Heptanal & 7.10 & 909 & Fishy, oily & $\begin{array}{l}\text { (Watson. } \\
2004 \text { ) }\end{array}$ \\
\hline 5 & $\begin{array}{l}\text { Septic, } \\
\text { stinky }\end{array}$ & Septic & Diethyl disulfide & 7.39 & 917 & $\begin{array}{l}\text { Septic, } \\
\text { rancid, } \\
\text { rotten egg }\end{array}$ & $\begin{array}{l}\text { (Suffet et } \\
\text { al. 2004; } \\
\text { Watson. } \\
\text { 2004) }\end{array}$ \\
\hline 6 & $\begin{array}{l}\text { Medicinal, } \\
\text { plastic }\end{array}$ & Medicinal & Phenol & 8.25 & 940 & $\begin{array}{l}\text { Medicinal, } \\
\text { wet paper }\end{array}$ & $\begin{array}{l}\text { (Young et } \\
\text { al. 1996) }\end{array}$ \\
\hline 7 & $\begin{array}{l}\text { Medicinal, } \\
\text { plastic }\end{array}$ & Medicinal & 2-Chlorophenol & 8.35 & 943 & $\begin{array}{l}\text { Medicinal, } \\
\text { musty, } \\
\text { antiseptic }\end{array}$ & $\begin{array}{l}\text { (Young et } \\
\text { al. 1996; } \\
\text { Watson. } \\
\text { 2004) }\end{array}$ \\
\hline 8 & $\begin{array}{l}\text { Chemical, } \\
\text { solvent }\end{array}$ & Chemical & $\begin{array}{l}1,4- \\
\text { Dichlorobenzene }\end{array}$ & 11.82 & 1042 & $\begin{array}{l}\text { Chemical, } \\
\text { antiseptic, } \\
\text { almond }\end{array}$ & $\begin{array}{l}\text { (Young et } \\
\text { al. 1996) }\end{array}$ \\
\hline 9 & $\begin{array}{l}\text { Chemical, } \\
\text { solvent }\end{array}$ & Chemical & Nitrobenzene & 12.72 & 1069 & $\begin{array}{l}\text { Chemical, } \\
\text { antiseptic }\end{array}$ & $\begin{array}{l}\text { (Suffet et } \\
\text { al. 2004; } \\
\text { Watson. } \\
\text { 2004) }\end{array}$ \\
\hline 10 & $\begin{array}{l}\text { Septic, } \\
\text { stinky }\end{array}$ & Septic & Propyl disulfide & 14.54 & 1127 & $\begin{array}{l}\text { Septic, } \\
\text { rancid, } \\
\text { rotten egg }\end{array}$ & $\begin{array}{l}\text { (Suffet et } \\
\text { al. 2004; } \\
\text { Watson. } \\
\text { 2004) }\end{array}$ \\
\hline 11 & $\begin{array}{l}\text { Musty, } \\
\text { earthy }\end{array}$ & Musty & 2-MIB & 15.81 & 1169 & $\begin{array}{l}\text { Musty, } \\
\text { earthy }\end{array}$ & $\begin{array}{l}\text { (Watson. } \\
\text { 2004) }\end{array}$ \\
\hline 12 & $\begin{array}{l}\text { Septic, } \\
\text { stinky }\end{array}$ & Septic & Indole & 16.15 & 1180 & $\begin{array}{l}\text { Septic, } \\
\text { marshy }\end{array}$ & $\begin{array}{l}\text { (Suffet et } \\
\text { al. 2004; } \\
\text { Watson. } \\
\text { 2004) }\end{array}$ \\
\hline
\end{tabular}




\begin{tabular}{|c|c|c|c|c|c|c|c|}
\hline 13 & $\begin{array}{l}\text { Medicinal, } \\
\text { musty }\end{array}$ & Medicinal & $\begin{array}{l}\text { 2-tert- } \\
\text { Butylphenol }\end{array}$ & 18.89 & 1277 & $\begin{array}{l}\text { Medicinal, } \\
\text { musty, wet } \\
\text { paper }\end{array}$ & $\begin{array}{l}\text { (Young et } \\
\text { al. 1996; } \\
\text { Watson. } \\
\text { 2004) }\end{array}$ \\
\hline 14 & $\begin{array}{l}\text { Musty, } \\
\text { earthy }\end{array}$ & Musty & Geosmin & 21.76 & 1387 & $\begin{array}{l}\text { Earthy, } \\
\text { musty }\end{array}$ & $\begin{array}{l}\text { (Watson. } \\
2004 \text { ) }\end{array}$ \\
\hline 15 & $\begin{array}{l}\text { Grassy, } \\
\text { chemical, } \\
\text { plastic }\end{array}$ & Chemical & cis-3-Hexenol & 6.25 & 887 & $\begin{array}{l}\text { Green, } \\
\text { grassy, } \\
\text { melon } \\
\text { rind-like } \\
\text { with a } \\
\text { pungent } \\
\text { freshness }\end{array}$ & $\begin{array}{l}\text { (Watson. } \\
2004 \text { ) }\end{array}$ \\
\hline 16 & Fishy, oily & Fishy & 2,4-Heptadienal & 7.78 & 927 & Fishy, oily & $\begin{array}{l}\text { (Watson. } \\
2004 \text { ) }\end{array}$ \\
\hline 17 & $\begin{array}{l}\text { Medicinal, } \\
\text { plastic }\end{array}$ & Medicinal & 2-Methylphenol & 11.05 & 1019 & $\begin{array}{l}\text { Medicinal, } \\
\text { musty, wet } \\
\text { paper }\end{array}$ & $\begin{array}{l}\text { (Young et } \\
\text { al. 1996; } \\
\text { Watson. } \\
\text { 2004) }\end{array}$ \\
\hline
\end{tabular}

\section{Figures}




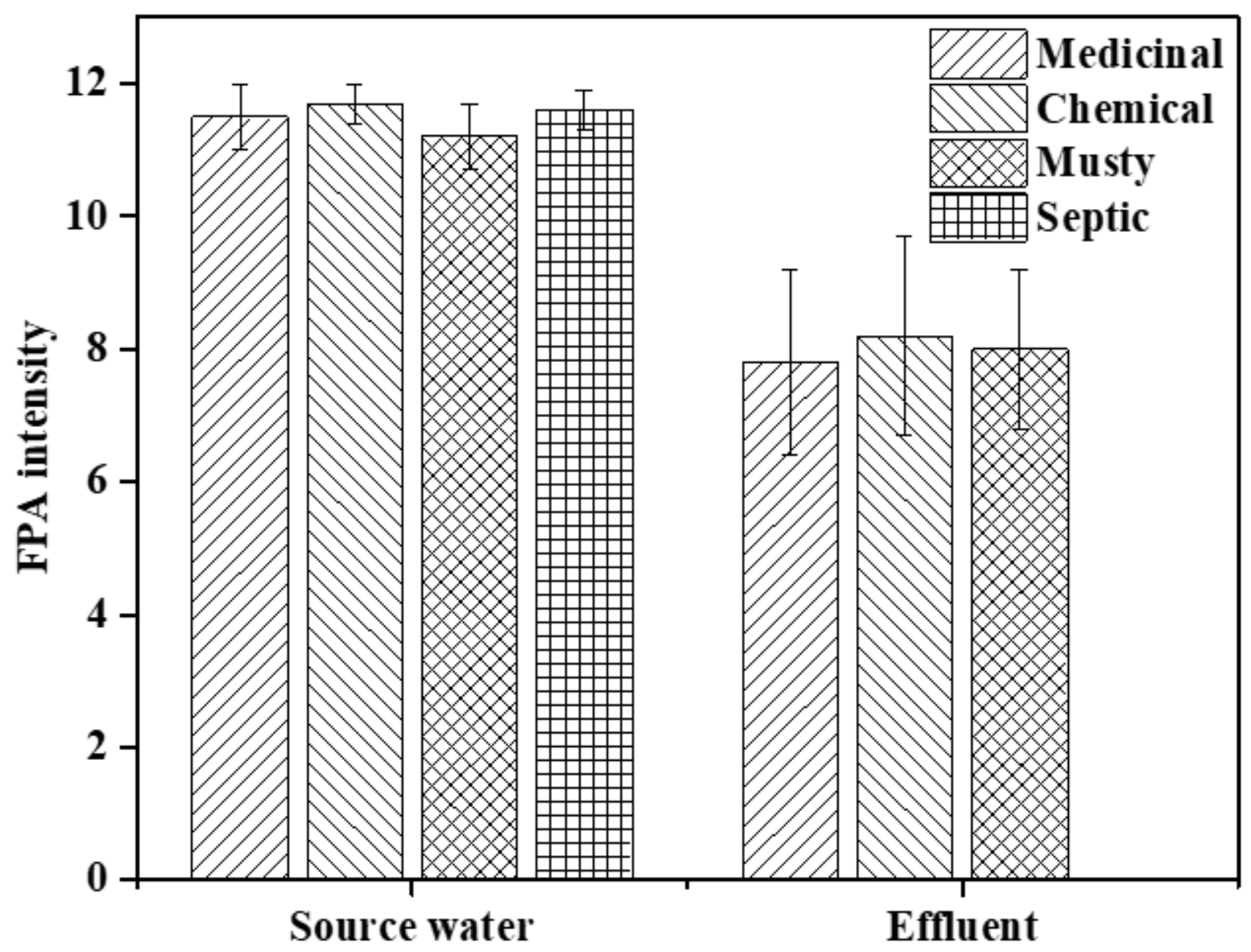

Figure 1

Odor characteristics of source water and effluent of DWTP located at QT River 


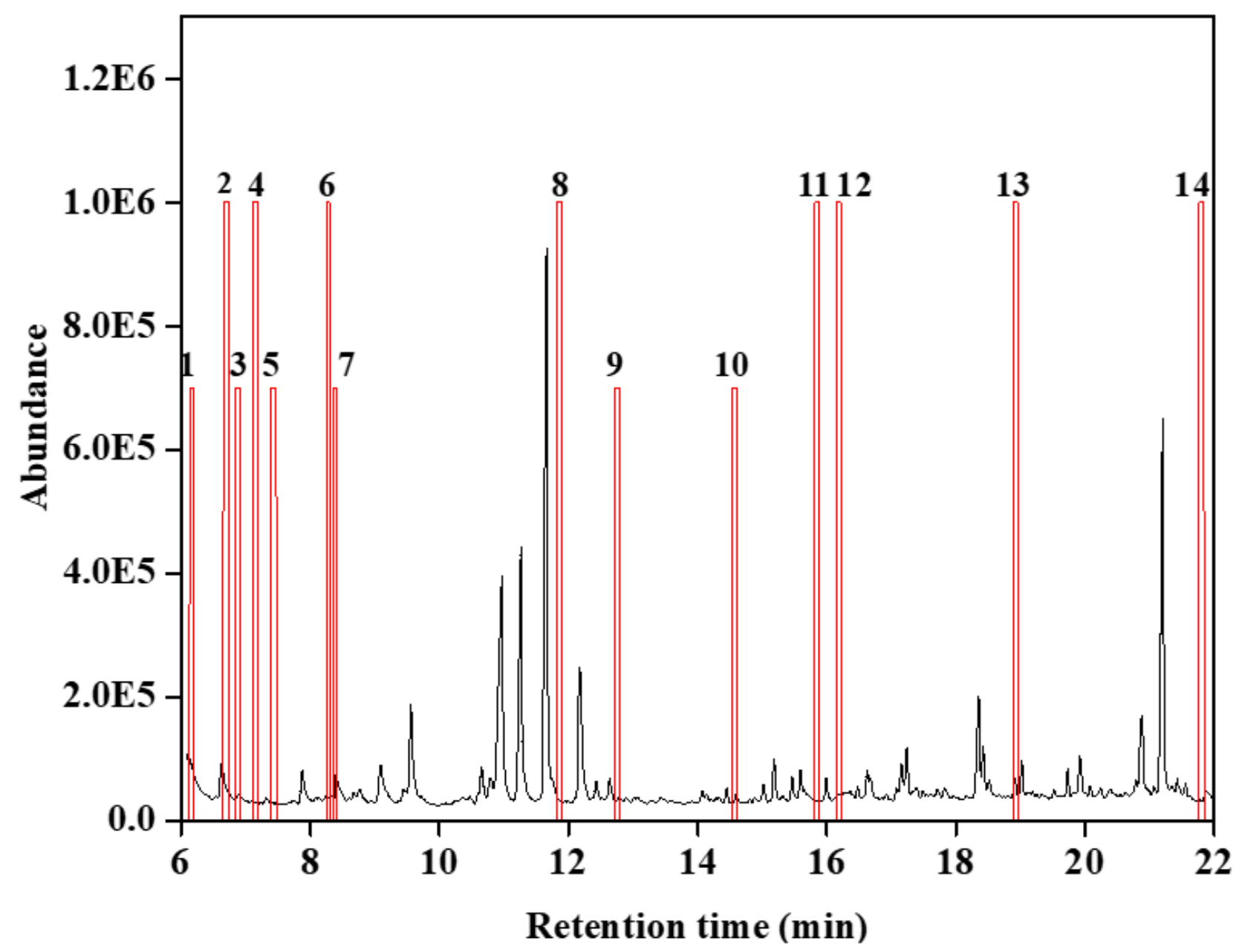

Figure 2

Odor peaks overlaid on a GC-O/MS chromatogram for source water of QT River in full-scan mode, preconcentration method: LLE, pre-concentration factor: 1000, the red line (histogram): olfactory peaks detected by GC-0, 1: medicinal, 2: septic, 3: chemical, 4: fishy, 5: septic, 6: medicinal, 7: medicinal, 8: chemical, 9: chemical, 10: septic, 11: musty, 12: septic, 13: medicinal, 14: earthy 


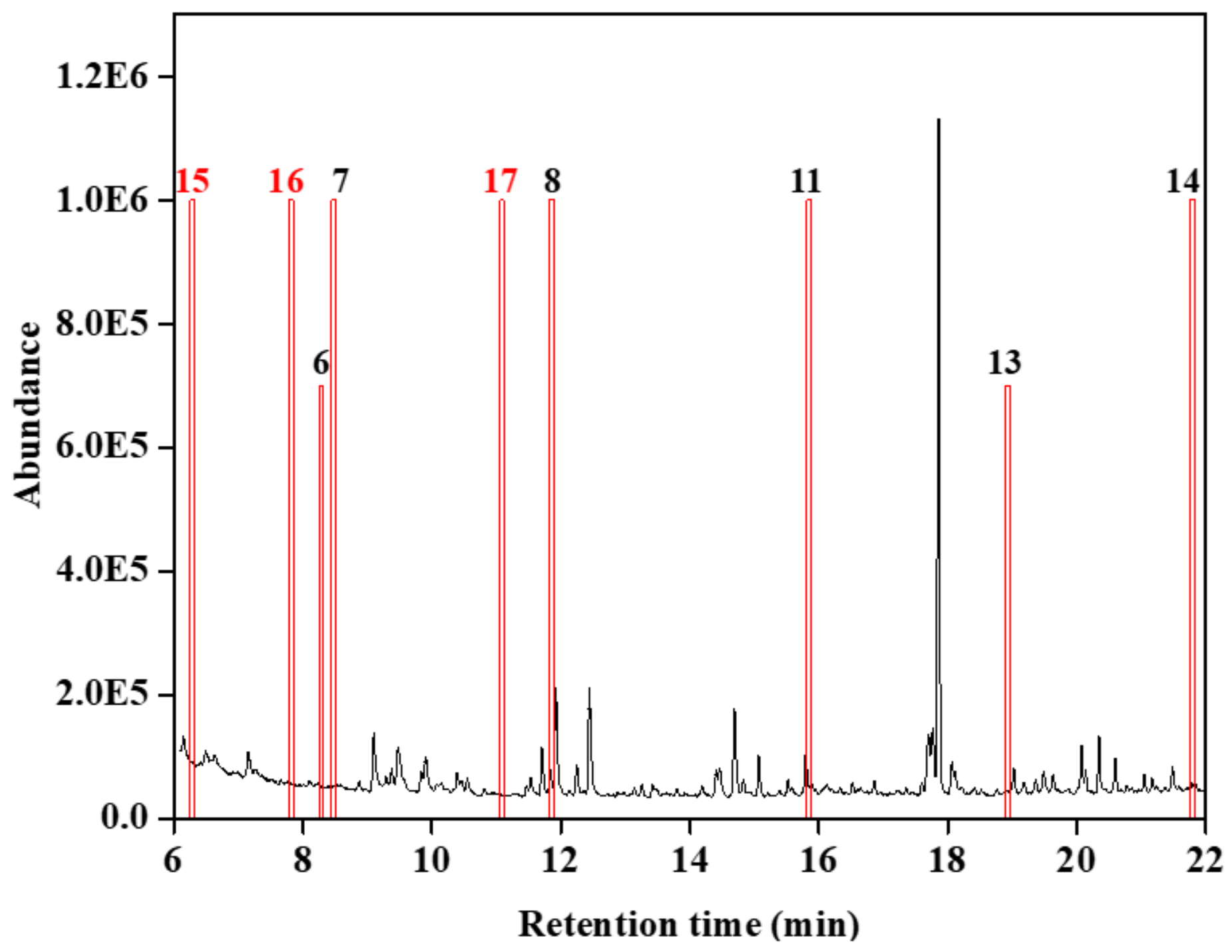

Figure 3

Odor peaks overlaid on a GC-O/MS chromatogram for effluent of DWTP located at QT River in full-scan mode, pre-concentration method: LLE, pre-concentration factor: 1000, the red line (histogram): olfactory peaks detected by GC-0, 6: medicinal, 7: medicinal, 8: chemical, 11: musty, 13: medicinal, 14: earthy, 15: chemical, 16: fishy, 17: medicinal 


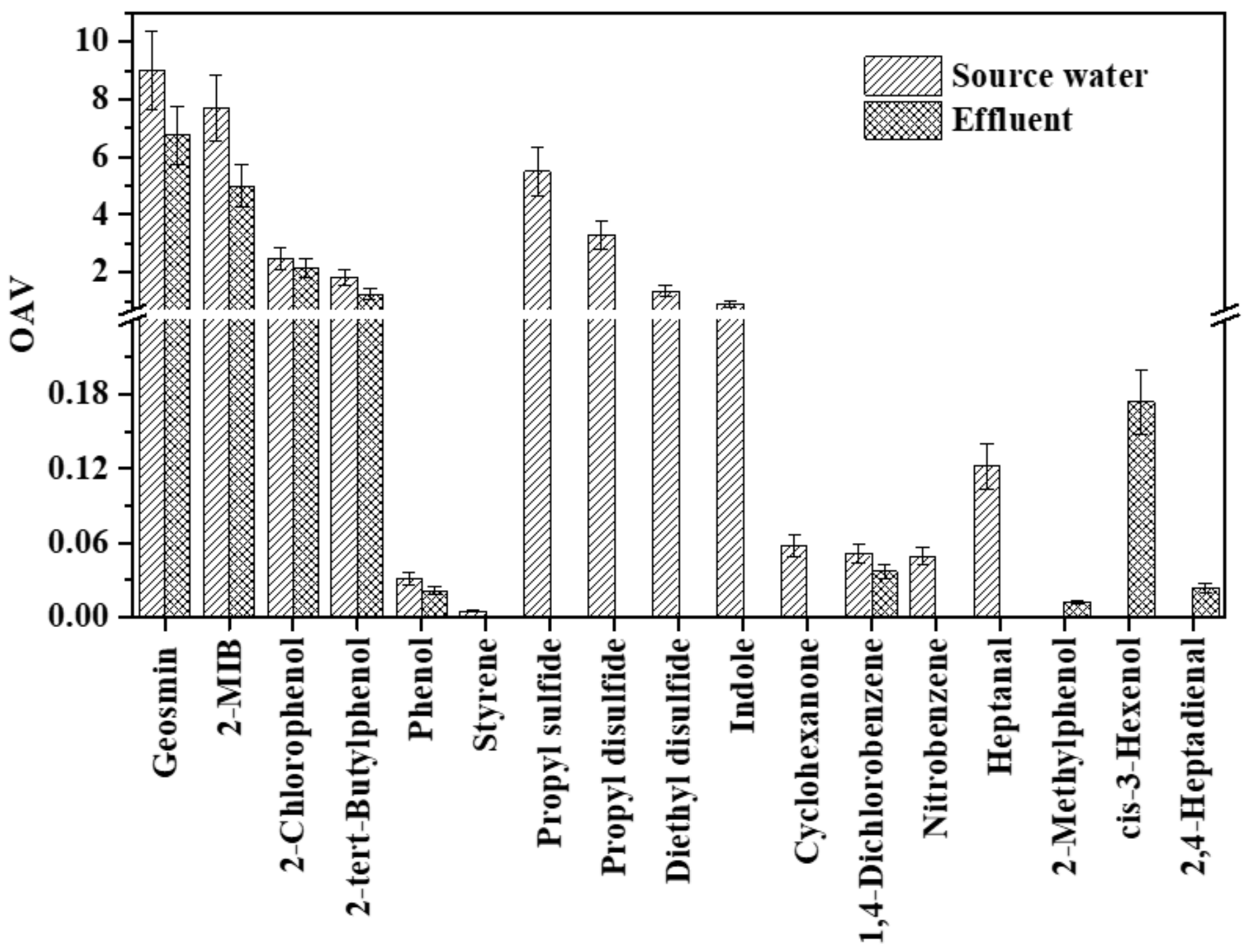

Figure 4

OAV ranking of odorants identified in source water and effluent of DWTP located at QT River 


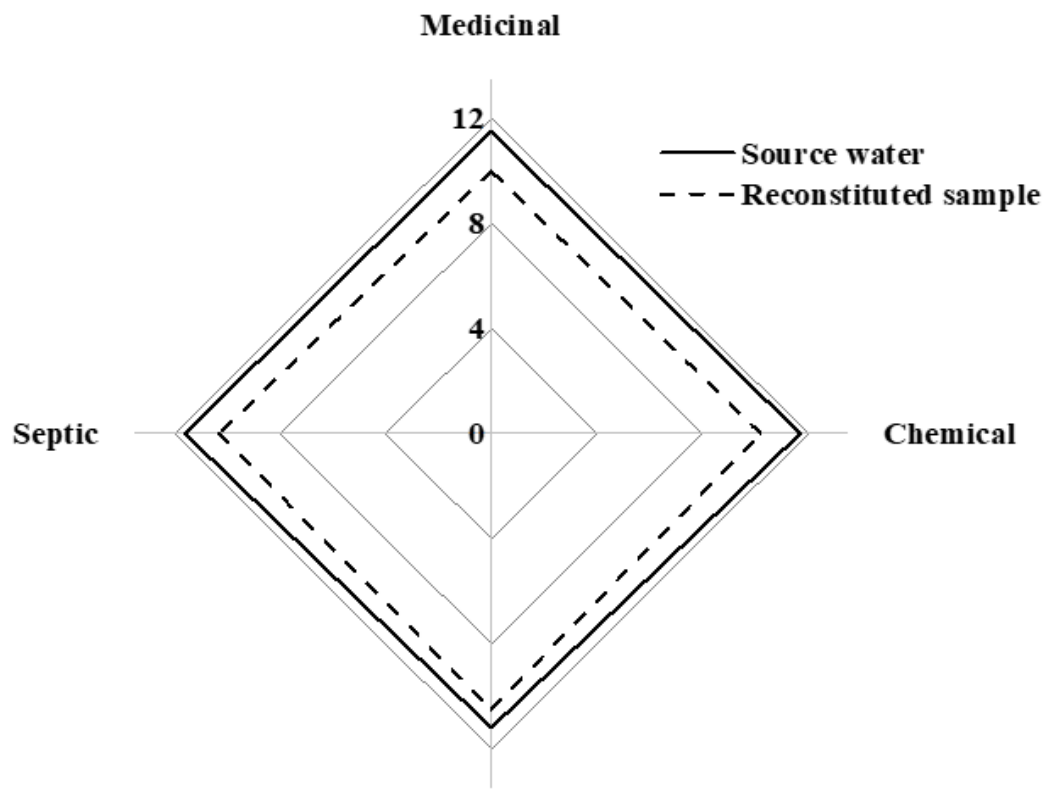

Musty

(a)

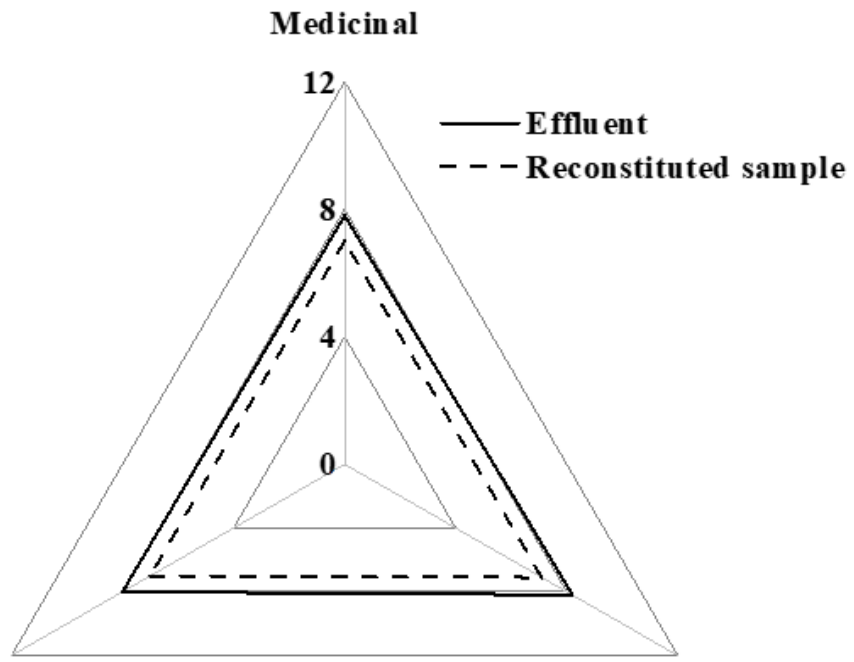

Musty

Chemical

(b)

\section{Figure 5}

Odor characteristics of source water, effluent of DWTP located at QT River and corresponding reconstituted samples in odorless waters, (a): source water, (b): effluent 


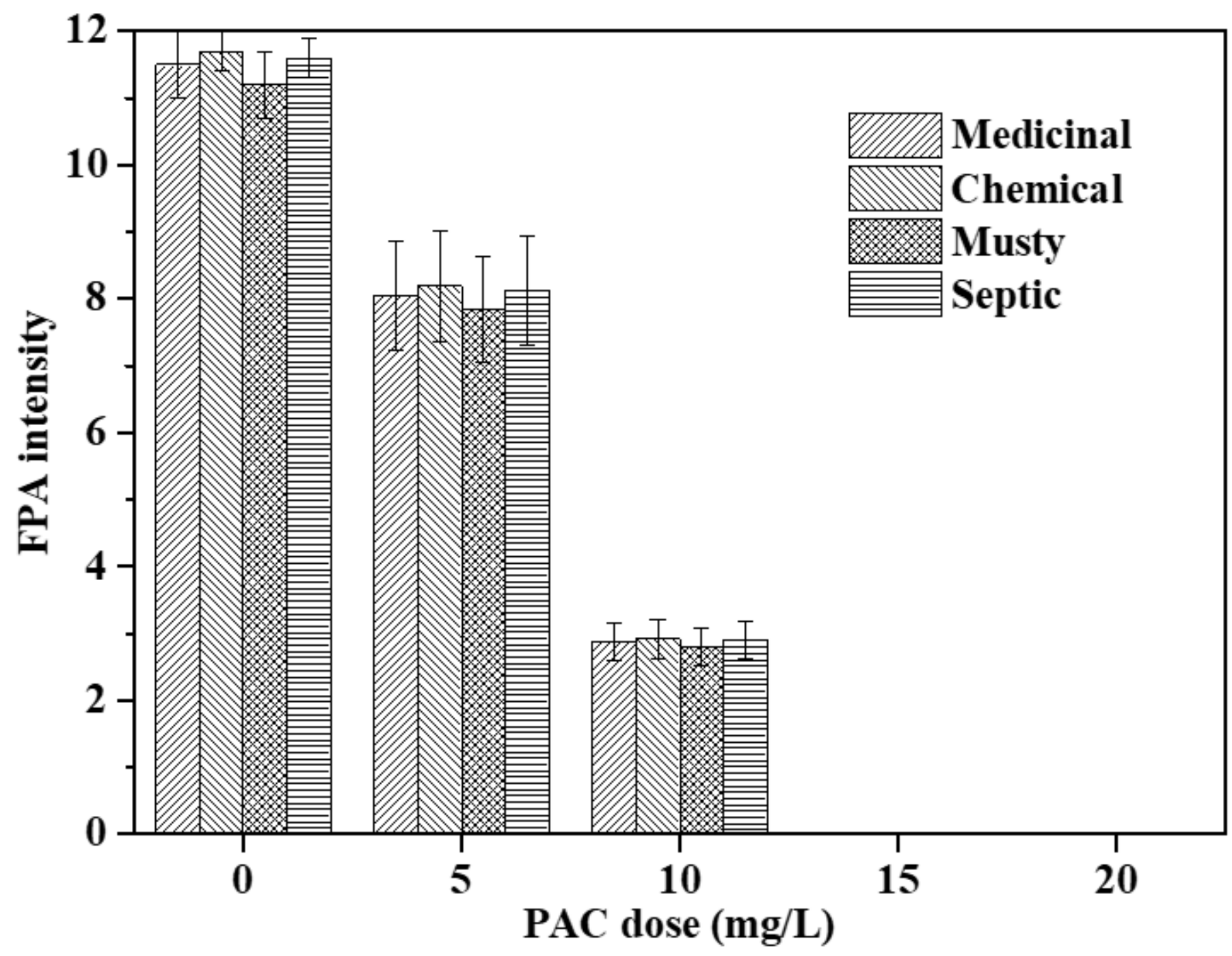

Figure 6

Effect of PAC with gradient doses on removing odors of source water in QT River, medicinal, chemical, musty, septic odors were completely removed after adding 15 and $20 \mathrm{mg} / \mathrm{L}$ PAC, no data were shown on corresponding PAC dose.

\section{Supplementary Files}

This is a list of supplementary files associated with this preprint. Click to download.

- Supportinginformation523.doc 